a notice was given of the junction of the Carboniferous and Silurian rocks at a locality called M'Cara's Brook.

Feb. 5.-A paper was read "On Raised Beaches and the Shells found in them, occurring on the coast of Essex near Walton." By J. Brown, Esq., of Stanway.

The object of this paper was to direct attention to the fact, that low raised beaches exist on this part of the eastern coast, and that they contain fossils, not only marine but freshwater, and confined to a small number of species, though individuals are very numerous. It was also the wish of Mr. Brown to bring these raised beaches into comparison with the beds called "Till" in the Clyde valley.

A paper was next read "On the Geology of the vicinity of the Wollondilly River, in Argyle County, in the colony of Sydney, New South Wales." By the Rev. W. B. Clarke.

The district described by the author is chiefly occupied by igneous rocks, upon which sedimentary rocks of the carboniferous period repose unconformably. The igneous rocks consist of granite and syenite, of porphyries, basalt and trachyte. They pass into and occasionally intersect one another, and are traversed by numerous dykes of igneous rocks of various kinds. The sedimentary rocks are not less violently disturbed, and have become greatly altered in every place where they have been brought into contact with the granite.

A communication was also made by Dr. Fitton, "On the Beds of the Lower Greensand of the Isle of Wight."

Dr. Fitton, after describing the general structure of the back of the Isle of Wight, alluded to the numerous fissures or chines found in these localities. He also described the different beds of the lower greensand, and mentioned the fossils most characteristic of each of them. He concluded by alluding to some of the fossils from the Neocomian beds of the Continent, and mentioned the fact that these foreign strata are strictly contemporaneous with the lower greensand of England.

\title{
MISCELLANEOUS.
}

FALCO ISLANDICUS.

A sPecimen of the Iceland falcon (Falco Islandicus) was shot near the North Tyne last week. It was a young male bird of the last year. This species was for a long time considered identical with the Gyr falcon of Greenland, until the difference was pointed out by Mr. J. Hancock, during the week that the meetings of the British Association for the Advancement of Science were held in Newcastle*. It is a very rare species in England, few instances of its capture being on record. In Iceland it appears to be not very uncommon during the summer months, where it breeds, but its equatorial migrations do not generally bring it so far south. The flight of these birds is powerful in the extreme. Montagu reckons that of the peregrine falcon (which is a closely-allied species to the present, but smaller) to be 150 miles an hour. At this speed, the distance from Iceland to this country would be easily performed. The present bird, which

* Mr. Hancock's paper will be found at p. 241, vol.ii. of the 'Annals.' 
is now in the possession of Mr. Charles Adamson of this town, was in good condition, weighing $2 \frac{1}{2}$ pounds.-Morning Chronicle of Feb. 6 .

\section{ON THE ORIGIN OF THE CORMS OF COLCHICUM.}

At the sitting of the Society of the Friends of Natural History of Berlin on the 19th of November, M. Link exhibited a corm of Colchicum arenarium, on which a flower-bud and the traces of two stems past flowering occurred, one of which was situated in the middle with the root-fibres. This proves that the base of the flower whence the root-fibres take their origin, and which during the flowering period is very small, subsequently increases in size and forms the true corm, traces of the stem of which, raised by the upward growth, are long visible. The growth of the corm, in which many have expected to find some regularity, is very irregular. Colchicum arenarium, which developes more flowers at one time than $C$. autumnale, exhibits this most distinctly.-Bot. Zeitung, Jan. 10, 1845.

\section{INFUSORIAL DEPOSITS IN AMERICA.}

" Charleston is built upon a bed of animalcules several hundred feet in thickness, every cubic inch of which is filled with myriads of perfectly preserved microscopic shells. These shells however do not, like those beneath Richmond and Petersburg, \&c., belong to the siliceous infusoria, but are all derived from those minute calcareousshelled creatures, called by Ehrenberg Polythalamia, and by D'Orbigny the Foraminifera. You are aware that Ehrenberg proved chalk to be chiefly made up of such shells, and you will doubtless be pleased to learn that the tertiary beds beneath your city are filled with more numerous and more perfect specimens of these beautiful forms than I have ever seen in chalk or marl from any other locality.

"The following are some of the results I have obtained:-

" 1 . The marls from the depth of 110 feet to 193 feet are certainly tertiary deposits, for I found them to contain Polythalamia of the family Plicatilia of Ehrenberg (Agathestegens of D'Orbigny), which family, as far as is yet known, occurs in no formation older than the tertiary.

" 2 . The beds from the depth of 193 feet to 309 feet contain so many species in common with the beds above them, that although I have not yet detected the Plicatilia, I still believe they must also belong to the tertiary formation.

" 3 . The forms found in these beds agree much better with those detected by me in the eocene marls from Panumkey River, Virginia, than they do with miocene Polythalamia from Petersburg, Va., and I am consequently inclined to believe that they belong to the eocene epoch.

" 4 . All the marls to the depth of 236 feet present the Polythalamia in vast abundance, and in a state of surprising preservation. The most delicate markings of the shells are perfectly preserved, and some of the forms are so large that they may be easily seen with a common pocket-lens.

“ 5 . The lithological characters of the marls from 236 feet to 309 


\section{$2 \mathrm{BHL}$ Biodiversity Heritage Library}

1845. "Falco Islandicus." The Annals and magazine of natural history; zoology, botany, and geology 15, 213-214. https://doi.org/10.1080/037454809495297.

View This Item Online: https://www.biodiversitylibrary.org/item/19398

DOI: https://doi.org/10.1080/037454809495297

Permalink: https://www.biodiversitylibrary.org/partpdf/23864

\section{Holding Institution}

Natural History Museum Library, London

\section{Sponsored by}

Natural History Museum Library, London

\section{Copyright \& Reuse}

Copyright Status: Public domain. The BHL considers that this work is no longer under copyright protection.

This document was created from content at the Biodiversity Heritage Library, the world's largest open access digital library for biodiversity literature and archives. Visit BHL at https://www.biodiversitylibrary.org. 